Article

\title{
Screening of Organic Substrates for Solid-State Fermentation, Viability and Bioefficacy of Trichoderma harzianum AS12-2, a Biocontrol Strain Against Rice Sheath Blight Disease
}

\author{
Shahram Naeimi ${ }^{1}\left(\mathbb{D}\right.$, Vahid Khosravi ${ }^{2}$, András Varga ${ }^{3}$, Csaba Vágvölgyi ${ }^{3}$ (D) \\ and László Kredics ${ }^{3, * \mathbb{D}}$ \\ 1 Department of Biological Control Research, Iranian Research Institute of Plant Protection, \\ Agricultural Research, Education and Extension Organization (AREEO), Tehran 19858-13111, Iran; \\ sh.naeimi@areeo.ac.ir \\ 2 Rice Research Institute of Iran, Mazandaran Branch, Agricultural Research, \\ Education and Extension Organization (AREEO), Amol 46191-91951, Iran; khosraviv@yahoo.com \\ 3 Department of Microbiology, Faculty of Science and Informatics, University of Szeged, Közép fasor 52., \\ 6726 Szeged, Hungary; vandras94@gmail.com (A.V.); csaba@bio.u-szeged.hu (C.V.) \\ * Correspondence: kredics@bio.u-szeged.hu; Tel.: +36-62-544516
}

Received: 18 July 2020; Accepted: 23 August 2020; Published: 26 August 2020

\begin{abstract}
The present study was undertaken to find the most suitable organic substrates for the biomass production, viability and efficacy of the biocontrol strain Trichoderma harzianum AS12-2 in the solid-state fermentation system. In total, 13 inexpensive, locally available substrates (agricultural wastes or by-products) were inoculated with the antagonist, and following one month of incubation at room temperature, all colonized substrates were air dried and ground to powder. The shelf life and viability of the Trichoderma strain were assessed as colony-forming units per gram (CFUs $\mathrm{g}^{-1}$ ) of each substrate on a monthly basis for up to one year at room temperature $\left(25 \pm 2{ }^{\circ} \mathrm{C}\right)$ and in the refrigerator $\left(4^{\circ} \mathrm{C}\right)$. In order to find out the effect of the substrate on the bioefficacy of T. harzianum AS12-2, the biocontrol potential of the formulations was evaluated against rice sheath blight disease caused by Rhizoctonia solani. The results showed that the fungus colonized more or less all substrates after one month, although the degree of colonization and conidiation was different among the substrates, being especially high in broom sorghum grain, rice husk, rice straw, rice bran and sugar beet pulp. Analysis of variance (ANOVA) of the population in the substrates in "Month 0" showed that the effect of treatment was significant, and the means were significantly different. The maximum population was recorded for broom sorghum grain and rice straw $\left(6.4 \times 10^{10}\right.$ and $5.3 \times 10^{10} \mathrm{CFUs} \mathrm{g}^{-1}$, respectively). The population declined in all substrates after one year of incubation at room temperature. This decline was relatively smaller in broom sorghum grain, rice straw and rice husk. On the other hand, the population in the same substrate incubated in the refrigerator was decreased in a mild slope, and the final population was high. In addition, the results of greenhouse assay showed that all bioformulations were effective in controlling the disease, and there were no significant differences among the substrates. According to the results of this study, broom sorghum grain, rice husk, rice straw, sugar beet pulp and cow dung could be recommended as suitable fermentation media for the industrial-scale production of T. harzianum strains.
\end{abstract}

Keywords: agricultural waste; biological control; biomass; fermentation media; rice sheath blight; shelf life; solid state fermentation; sporulation; Trichoderma 


\section{Introduction}

The application of chemical pesticides is the most common way to protect plants against pests and diseases in agriculture. However, the use of synthetic compounds adversely affects the environment and human health [1,2]. In addition, the high cost of investigating, developing and registering new synthetic pesticides, and the rapid emergence of pathogen resistance, have also contributed to an increased interest in finding alternate disease control methods [3]. In recent years, the global production, registration and application of biological pesticides in agriculture as an alternative to chemicals has been rapidly increasing due to public concerns about human health, food safety, and impact on the environment $[4,5]$. Many companies are attracted by the idea of developing environment-friendly products, and several commercial biopesticides are currently being used for the efficient control of plant disease, resulting in the improved productivity of many crops [6]. Biocontrol based on antagonistic microorganisms is an effective and sustainable approach that has numerous advantages, including increased crop yield, safety for humans and other non-target organisms, reduction of pesticide residues in food, water, and soil, as well as increased biodiversity [7-9].

Once biocontrol agents (BCAs) are identified and proven to be effective against plant pathogens, they have the potential to be developed into commercial biopesticides [10]. However, the development of a microbial product is a time-consuming and costly procedure, and in order to commercialize a beneficial microbe, there are some obstacles to its production, formulation, registration and field application [6]. The formulation of BCAs and their bioefficacy greatly depends on the quantity and quality of fungal biomass [11,12]. Nevertheless, a crucial aspect in the commercialization of a microbial biopesticide is the accessibility of an economical mass production technology that provides an abundant and effective form of the biocontrol agent $[13,14]$. A fermentation substrate should be nutrient-rich, low-cost and easily available, resulting in the production of sufficient biomass, containing potent inoculum $[15,16]$. Moreover, the biomass of fungal biocontrol agents must survive several processing steps, including harvesting, drying, formulation, storage and delivery [17]. In this sense, poor shelf life is regarded as a major obstacle to commercializing microbial biopesticides [18]. The shelf life of the microbial product should be improved by using appropriate organic substrates via a suitable production method that results in biomass of both high quantity and quality [19].

Solid-state fermentation (SSF) and liquid state fermentation or submerged fermentation (SmF) are two methods for the propagule production of fungal biocontrol agents [15]. SSF has appeared as a suitable technology for the production of microbial biomass [20], and is defined as a process that involves the cultivation of microorganisms on an organic solid substrate, which is generally a non-soluble material that serves as physical support as well as nutrient source [21]. Filamentous fungi are the most frequently used microorganisms for SSF technology [22]. SSF is applied at the commercial scale in the industry for the production of value-added products, such as enzymes, secondary metabolites, antibiotics, organic acids, biofuels, conidia and biomass, by a variety of fungi $[23,24]$. It is performed in various containers, such as plates, beakers, flasks, bottles, bags, trays and column bioreactors [25]. SSF has noticeable economic potential in the biopesticide industry [26,27], and offers several advantages over $\mathrm{SmF}$, including higher fermentation productivity, higher product stability, lower capital and operating costs, simpler equipment and media, lower water and energy requirements, less technical difficulties, no need to control several parameters, easier downstream processing and lower demand on sterility due to the low water activity [27-31]. SSF simulates the natural conditions and habitat for fungi [22,32], and it is well adapted to the metabolism of these microorganisms [20]. The fungal spore is the most resistant propagule that survives adverse environmental conditions, especially desiccation $[29,33]$. SSF contributes to a higher number of hardy and healthy spores with longer viability and higher resistance to UV and other abiotic factors [34-37]. Moreover, SSF is suitable for producing fungi that do not sporulate in liquid media, or do not tolerate the SmF conditions [38]. Generally, organic substrates in SSF act as carriers for the biomass, and it is not necessary to develop a complicated formulation afterward [38]. Thus, SSF may be appropriate in developing countries where agricultural wastes are available, high-tech equipment is limited, and the workforce is abundant [39]. 
Another advantage of SSF over SmF is that SSF allows the valorization of agro-industrial wastes or by-products, so it provides a sustainable recovery of the resources [22,31,40]. However, SSF has some disadvantages, including higher fermentation time, difficulties on scale-up and in control of process parameters (i.e., substrate moisture level, $\mathrm{pH}$, temperature), as well as problems with heat build-up. Furthermore, homogenizing the solid substrate is not possible, causing temperature and composition gradients [25].

Production costs, partly due to the expensive substrates and low biomass yields, are among the most important reasons for the limited number of biofungicides on the market [41,42]. However, in the SSF process, the microorganism is cultured on different types of organic matter, including agricultural wastes and by-products which are available at low cost. Various substrates can serve as suitable media for the production of inoculum of biocontrol fungi, including cereal grains (wheat, barley, corn, millets and sorghum), cereal brans, cereal straws, husks, meals, plant-based oil cakes, bagasse, molasses and sawdust $[22,24,29,43,44]$.

Trichoderma species are versatile, ubiquitous and abundant fungi found in many soil types in diverse ecosystems [45]. They have been known as biocontrol agents of plant pathogens for decades, and collectively are effective against various diseases of many crops in the greenhouse, nursery, field and orchards $[46,47]$. Trichoderma strains can act on plant pathogens through a number of mechanisms, such as antibiosis, hyperparasitism, enzyme production, induction of plant resistance, and competition for essential nutrients and space [48-50]. Additionally, these microbial agents also promote plant growth and abiotic stress tolerance against such disruptions as drought and salinity [51-54]. Members of the genus Trichoderma are widely studied fungi, and are among the most commonly used microbial BCAs in agriculture [55]. Owing to the multiple beneficial effects on plants, Trichoderma spp. comprise the majority of commercial fungal BCAs in agriculture, and are presently marketed as biopesticides, biofertilizers, growth enhancers, and stimulants of natural resistance $[8,56,57]$. The number of Trichoderma-containing products found on the international market has been rapidly growing to more than 250 available products [55].

Considerable amounts of studies have focused on the mass production of Trichoderma spp. in the hope of developing effective and safe bioproducts as substitutes for chemicals for the control of plant diseases [17,58-61]. The most common formulations of Trichoderma are wettable powder and granules [55,62], and SSF is a routine biological system for mass production [20,23,25,42,44,63-67].

The conidia of Trichoderma are the most efficient propagules that survive downstream processing [68]. For instance, the conidia of T. harzianum produced in aerial mycelium with SSF persist longer under adverse environmental conditions than those produced by SmF, and the wall thickness of aerial conidia is almost twice that of submerged ones [69]. Nevertheless, Trichoderma strains produce high levels of biomass, as well as conidia and chlamydospores in SSF [70]. Various agricultural waste materials, such as cereal grains, straw and brans, as well as sugarcane bagasse, ground corn cobs, sawdust, etc., have been frequently used to produce Trichoderma biocontrol strains [10].

The objective of the present study was to find, amongst 13 inexpensive and locally available substrates (agricultural wastes or by-products), the most suitable organic substrate for the colonization, conidiation, viability and bioefficacy of a biocontrol strain of T. harzianum against rice sheath blight, and to develop a low-cost solid-state fermentation process that could be used at the industrial scale.

\section{Materials and Methods}

\subsection{Biocontrol Strain}

Trichoderma harzianum AS12-2, a highly effective strain against Rhizoctonia solani in vitro and the rice sheath blight disease caused by this pathogen under greenhouse and field conditions [71-73], was used in this study. It was originally isolated from paddy soil and identified during previous studies on the basis of morphology as well as the sequence analysis of rDNA-ITS [71] and a fragment of the tef1 $\alpha$ gene [73] (GenBank accession numbers: EU821789 and FJ618586, respectively). 


\subsection{Organic Substrates}

Thirteen locally available and low-cost organic substrates, which are considered as agricultural wastes or by-products, were involved in this study. They were rice husk, crushed (powdered) rice husk, rice straw, rice bran, wheat bran, broom sorghum (Sorghum vulgare var. technicum) grain, sawdust, cow dung, sugar beet pulp, soybean meal, peanut pod, used barley grain (obtained from a local insect mass rearing unit), and water fern (Azolla filiculoides).

\subsection{Solid-State Fermentation}

For biomass production of T. harzianum AS12-2 [71-73], all substrates were soaked in tap water overnight, and excess water was drained out. Then, $300 \mathrm{~g}$ of each substrate was filled in $1 \mathrm{~L}$ conical flasks and sterilized in an autoclave three times at $121{ }^{\circ} \mathrm{C}$ for $30 \mathrm{~min}$ during three successive days. After cooling the substrates to room temperature, they were inoculated under aseptic conditions with three $5 \mathrm{~mm}$ mycelial discs cut from the edge of 2-day-old PDA cultures of the biocontrol fungus in order to have a uniform and full colonization of the organic substrates, then the flasks were sealed with sterile cotton wool and kept at ambient laboratory temperature for 30 days and periodically shaken by hand in order to have uniform growth of the BCA (Figure 1A). After incubation, Trichoderma inocula were taken from the flasks, air dried for up to 7 days in a clean room (Figure 1B), and ground to a powder with Mortar Grinder PULVERISETTE 2 (Fritsch, Germany).

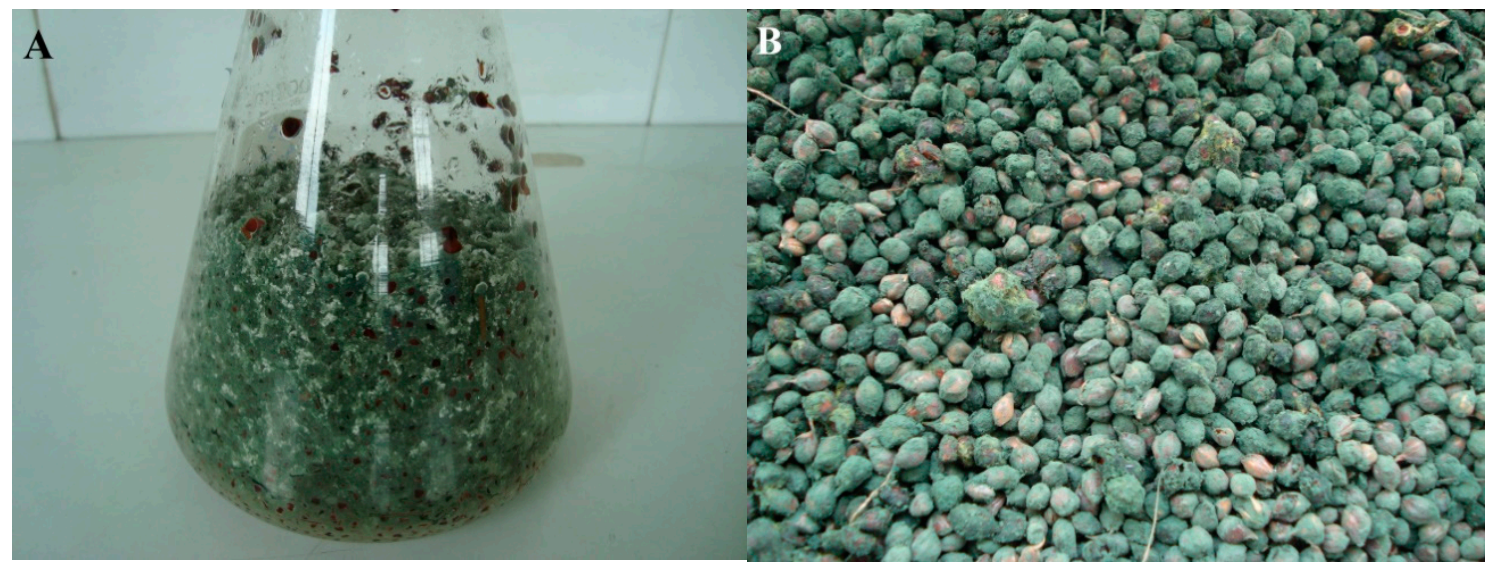

Figure 1. Solid state fermentation of T. harzianum AS12-2 strain on broom sorghum grains.

(A) Fermentation flask. (B) Grains colonized by T. harzianum after drying.

\subsection{Sporulation}

Conidium production of T. harzianum AS12-2 in all substrates was examined by the serial dilution method on potato dextrose agar (PDA, Merck, Germany) medium. Prior to plating, $1 \mathrm{~g}$ dried sample of each solid fermented substrate was suspended in $9 \mathrm{~mL}$ sterile distilled water. Suspensions were vigorously shaken using a vortex mixer for $1 \mathrm{~min}$, then serial dilutions were made and $200 \mu \mathrm{L}$ aliquots were plated on PDA medium in Petri dishes. The plates were incubated for 3-5 days in the dark at $25^{\circ} \mathrm{C}$, until Trichoderma colonies were visible. The number of colonies was enumerated visually, and results were recorded as colony-forming units (CFUs) per gram of dry substrates.

\subsection{Viability and Shelf Life}

All dried substrates were packed into $50 \mathrm{~mL}$ sterile plastic screw cap bottles (Falcon Plastics, Brookings, SD, USA) with three replicates for each temperature, sealed and stored at room temperature $\left(25 \pm 2{ }^{\circ} \mathrm{C}\right)$ and in the refrigerator $\left(4^{\circ} \mathrm{C}\right)$ until use. The shelf life of conidia of T. harzianum AS12-2 was assessed after 1 month and then monitored at a 3-month interval for 12 months. To determine the shelf life of conidia, $1 \mathrm{~g}$ samples from each dried substrate kept at each temperature were taken from 
the container, suspended in $9 \mathrm{~mL}$ sterile distilled water, and conidial production and viability were estimated as described above. The shelf life of the formulations during storage was expressed as log $\mathrm{CFU} \mathrm{g}^{-1}$.

\subsection{Biocontrol Efficacy}

An experiment was conducted to determine the biocontrol efficacy of the five best formulations (according to the results of colonization and shelf life studies) in relation to the rice sheath blight disease in greenhouse, according to Naeimi et al. [71]. The rice plants (cv. Shiroodi) were inoculated with $R$. solani RBL1 (obtained from the culture collection of the Rice Research Institute of Iran). A 5 -mm mycelial plug of the pathogen was placed between the junction of the basal leaf sheath and the stem above the water line at the maximum tillering stage. Three rice plants (five tillers per hill) were inoculated for each treatment. Biocontrol suspensions were made from each colonized substrate and the concentration of spores was adjusted to $10^{7}$ conidia per $\mathrm{ml}$ using a Neubauer Improved haemocytometer (Precicolor, HBG, Giessen, Germany). For each replicate plant, $50 \mathrm{~mL}$ of biocontrol suspension was evenly sprayed on the rice phyllosphere using a hand sprayer at two stages: $24 \mathrm{~h}$ after inoculation of the pathogen and seven days after the first spray. Propiconazole (TILT ${ }^{\circledR}, 250$ EC, Syngenta, Switzerland) was used as the chemical fungicide for comparison and applied as a foliar spray $\left(1 \mathrm{~L} \mathrm{ha}^{-1}\right)$. Plants inoculated only with $R$. solani were considered as infected control, while plants sprayed with distilled water served as non-infected control. Disease severity was recorded following the International Rice Research Institute's standard evaluation procedure for rice [74] as relative lesion height (RLH, the average vertical height of the uppermost lesion on leaf or sheath expressed as a percentage of the average plant height) 28 days after inoculation of the pathogen using the formula [71]:

$$
\text { RLH }(\%)=100 \times[\text { Highest point a lesion occurred }(\mathrm{cm}) / \text { Plant height }(\mathrm{cm})] .
$$

\subsection{Statistical Analysis}

All experiments were established as a completely randomized design with three replicates. The data were analyzed for significance with analysis of variance (ANOVA) using the SAS software ver. 9.1 (SAS Proc GLM; SAS Institute, Inc., Cary, NC, USA). The CFU values were transformed to $\log _{10}$ before statistical analysis. All means of the treatments were compared by Duncan's multiple range tests at $p \leq 0.01$.

\section{Results}

\subsection{Colonization and Sporulation}

The results showed that after one month, T. harzianum AS12-2 colonized all substrates to different intensities, from scanty growth to covering the whole substrate (Table 1). The solid media had a white color at first due to the development of the mycelium, then the color gradually changed and various shades of green were observed among the substrates. In addition, the level of conidiation was significantly different among the substrates, and the results of ANOVA showed that the effect of treatment on the fungal population in "Month 0 " (after one month of incubation, air drying and grinding of the substrates) was significant at $p \leq 0.01$. The highest conidiation occurred in broom sorghum grain and rice straw with $6.4 \times 10^{10}$ and $5.3 \times 10^{10} \mathrm{CFUs} \mathrm{g}^{-1}$, respectively, which were placed into one single statistical group (Table 1). Next to these two substrates, rice bran, rice husk and sugar beet pulp represented the highest populations, with $4.7 \times 10^{9}, 3.1 \times 10^{9}$ and $2.3 \times 10^{9} \mathrm{CFUs}$ $\mathrm{g}^{-1}$, respectively, which were not significantly different (Table 1). Soybean meal showed the least fungal population with scanty colonization and white fungal mass. Soybean meal, together with waste barley grain, water fern and sawdust, were abandoned due to poor colonization and conidiation of the biocontrol fungus, and the nine remaining substrates were selected for further studies. 


\subsection{Viability and Shelf Life}

After one month of incubation at room temperature, the population of T. harzianum AS12-2 on the substrates remained almost stable or decreased very slowly (Figure 2A), however in all nine substrates, the number of CFUs reduced with time during the 12 months of storage. The pattern of population decline in broom sorghum grain and rice straw, in which the maximum initial populations were observed $\left(6.4 \times 10^{10}\right.$ and $5.3 \times 10^{10} \mathrm{CFUs}^{-1}$, respectively), was similar. The population of the biocontrol fungus in both substrates declined slowly until Month 3, and then sharply decreased, and at the end reached $2.5 \times 10^{9}$ and $1.1 \times 10^{9} \mathrm{CFUs} \mathrm{g}^{-1}$, respectively, in Month 12 . In rice husk and sugar beet meal, the population dynamics of the fungus was similar until Month 6 . In fact, the population rose slowly until Month 3 and then dropped sharply until Month 6 . The population decline continued to Month 12 with a larger decrease in sugar beet meal, and the final populations were counted as $3.3 \times 10^{7}$ and $3.3 \times 10^{6} \mathrm{CFUs} \mathrm{g}^{-1}$, respectively. The reduction of the population in the crushed rice husk started from Month 1 and continued slowly to Month 12, reaching $2.2 \times 10^{7} \mathrm{CFUs} \mathrm{g}^{-1}$. The population changes in rice bran and wheat bran were similar: the viability of the biocontrol fungus rapidly reduced in both substrates from Month 2 to Month 12, but this reduction was considerably higher in wheat bran. The CFU numbers of the fungus per grams of rice and wheat bran were $1.2 \times 10^{7}$ and $5.8 \times 10^{5}$, respectively, at the end of Month 12. The populations of T. harzianum AS12-2 in peanut pod and cow dung declined similarly during the studied period, but showed a considerable decrease in peanut pod in Month 12, and finally the populations were calculated as $6.6 \times 10^{6}$ and $1.5 \times 10^{7} \mathrm{CFUs} \mathrm{g}^{-1}$, respectively.

Table 1. Colonization of Trichoderma harzianum AS12-2 in different substrates and its initial and final populations.

\begin{tabular}{|c|c|c|c|c|}
\hline Substrate & Colonization $^{a}$ & $\begin{array}{l}\text { Initial Population }{ }^{b} \\
\text { (CFU } g^{-1} \text { Substrate) }\end{array}$ & $\begin{array}{c}\text { Final Population }{ }^{c} \text { (CFU } \\
\mathrm{g}^{-1} \text { Substrate) }\end{array}$ & $\begin{array}{l}\text { Final Population }{ }^{d} \\
\text { (CFU g }{ }^{-1} \text { Substrate) }\end{array}$ \\
\hline Rice husk & +++ & $3.1 \times 10^{9} \pm 7.0 \times 10^{7 b c}$ & $3.3 \times 10^{7} \pm 7.8 \times 10^{6 b}$ & $3.8 \times 10^{8} \pm 2.2 \times 10^{7 b}$ \\
\hline Crushed rice husk & +++ & $1.2 \times 10^{9} \pm 7.2 \times 10^{7} \mathrm{~cd}$ & $2.2 \times 10^{7} \pm 4.3 \times 10^{6} b c$ & $1.6 \times 10^{8} \pm 2.8 \times 10^{7 c}$ \\
\hline Rice straw & +++ & $5.3 \times 10^{10} \pm 4.7 \times 10^{9} \mathrm{a}$ & $1.1 \times 10^{9} \pm 1.5 \times 10^{8 \mathrm{a}}$ & $1.0 \times 10^{10} \pm 7.2 \times 10^{8 \mathrm{a}}$ \\
\hline Rice bran & ++ & $4.7 \times 10^{9} \pm 5.8 \times 10^{8 b}$ & $1.2 \times 10^{7} \pm 1.4 \times 10^{6 \mathrm{~cd}}$ & $7.8 \times 10^{8} \pm 5.9 \times 10^{7 b}$ \\
\hline Wheat bran & ++ & $7.0 \times 10^{8} \pm 1.5 \times 10^{8 \mathrm{de}}$ & $5.8 \times 10^{5} \pm 8.9 \times 10^{4 f}$ & $1.1 \times 10^{8} \pm 1.8 \times 10^{7 c}$ \\
\hline Broom sorghum grain & +++ & $6.4 \times 10^{10} \pm 5.2 \times 10^{9 a}$ & $2.5 \times 10^{9} \pm 4.4 \times 10^{8 \mathrm{a}}$ & $1.5 \times 10^{10} \pm 2.3 \times 10^{9 a}$ \\
\hline Waste barley grain & ++ & $4.3 \times 10^{7} \pm 1.2 \times 10^{7 \mathrm{f}}$ & $\mathrm{n} / \mathrm{a}$ & $\mathrm{n} / \mathrm{a}$ \\
\hline Peanut pod & ++ & $3.7 \times 10^{8} \pm 9.6 \times 10^{7 e}$ & $6.6 \times 10^{6} \pm 7.1 \times 10^{5} \mathrm{de}$ & $3.3 \times 10^{7} \pm 9.5 \times 10^{6 \mathrm{~d}}$ \\
\hline Sugar beet pulp & +++ & $2.3 \times 10^{9} \pm 6.9 \times 10^{8 b c}$ & $3.3 \times 10^{6} \pm 7.8 \times 10^{5 \mathrm{e}}$ & $6.5 \times 10^{8} \pm 7.1 \times 10^{7 b}$ \\
\hline Soybean meal & + & $1.4 \times 10^{3} \pm 2.3 \times 10^{2 \mathrm{~h}}$ & $\mathrm{n} / \mathrm{a}$ & $\mathrm{n} / \mathrm{a}$ \\
\hline Cow dung & +++ & $2.7 \times 10^{8} \pm 2.5 \times 10^{7 \mathrm{e}}$ & $1.5 \times 10^{7} \pm 2.3 \times 10^{6 \mathrm{bcd}}$ & $9.0 \times 10^{7} \pm 4.7 \times 10^{6 c}$ \\
\hline Water fern & +++ & $2.0 \times 10^{6} \pm 3.8 \times 10^{5} \mathrm{~g}$ & $\mathrm{n} / \mathrm{a}$ & $\mathrm{n} / \mathrm{a}$ \\
\hline Sawdust & + & $3.2 \times 10^{6} \pm 3.3 \times 10^{5} \mathrm{~g}$ & $\mathrm{n} / \mathrm{a}$ & $\mathrm{n} / \mathrm{a}$ \\
\hline
\end{tabular}

(a) Colonization intensity, +++ : high; ++ : medium; +: low. (b) Initial population of biocontrol fungus after one month of incubation of the substrates at room temperature $\left(25 \pm 2{ }^{\circ} \mathrm{C}\right)$. (c) Final population of the biocontrol fungus after 12 months of incubation of the substrates at room temperature $\left(25 \pm 2{ }^{\circ} \mathrm{C}\right)$. $(d)$ Final population of the biocontrol fungus after 12 months of incubation of the substrates inside a refrigerator $\left(4^{\circ} \mathrm{C}\right)$. Data present mean values \pm standard error from three replicates. Values in each column followed by the same letter in superscript are not significantly $(p \leq 0.01)$ different according to the Duncan's multiple range test. n/a: not available (these substrates not included in viability analysis).

In comparison, the populations of T. harzianum AS12-2 in all substrates (except for rice husk and peanut pod) decreased gradually when they were refrigerated at $4{ }^{\circ} \mathrm{C}$ for over one year of storage (Figure 2B). In the rice husk (both crushed and uncrushed) and peanut pod substrates, the viability slowly declined until Month 3 and Month 6, respectively, then it sharply decreased afterwards. Likewise, the population gradually decreased in peanut pod until Month 6, and then it steeply declined. Despite the loss of viability of the biocontrol fungus in all substrates during their incubation in the refrigerator, this population decline was considerably low compared to the incubation of the same substrates at room temperature.

The initial and final populations of T. harzianum AS12-2 in all substrates at both temperatures are shown in Table 1. The results of ANOVA show that the effect of treatment on the fungal population in Month 12 (end of incubation) was significant at both temperatures $(p \leq 0.01)$. 
Table 2. Efficacy of different organic substrates containing Trichoderma harzianum AS12-2 in controlling rice sheath blight in the greenhouse.

\begin{tabular}{lc}
\hline Treatment & Disease Severity (\%) ${ }^{a}$ \\
\hline Crushed rice husk & $31.84 \pm 3.14^{\mathrm{b}}$ \\
Rice straw & $30.24 \pm 2.81^{\mathrm{b}}$ \\
Broom sorghum grain & $30.29 \pm 2.18^{\mathrm{b}}$ \\
Sugar beet pulp & $34.94 \pm 3.72^{\mathrm{b}}$ \\
Cow dung & $34.06 \pm 1.92^{\mathrm{b}}$ \\
Propiconazole & $16.90 \pm 1.53^{\mathrm{c}}$ \\
Infected control & $68.10 \pm 4.68^{\mathrm{a}}$ \\
Non-infected control & $0.00 \pm 0.00^{\mathrm{d}}$ \\
\hline
\end{tabular}

(a) Sheath blight severity was calculated as relative lesion length (RLH) four weeks after the artificial inoculation of the pathogen, Rhizoctonia solani. Data present mean values \pm standard error from three replicates. Values in each column followed by the same letter in superscript are not significantly $(p \leq 0.01)$ different according to the Duncan's multiple range test.
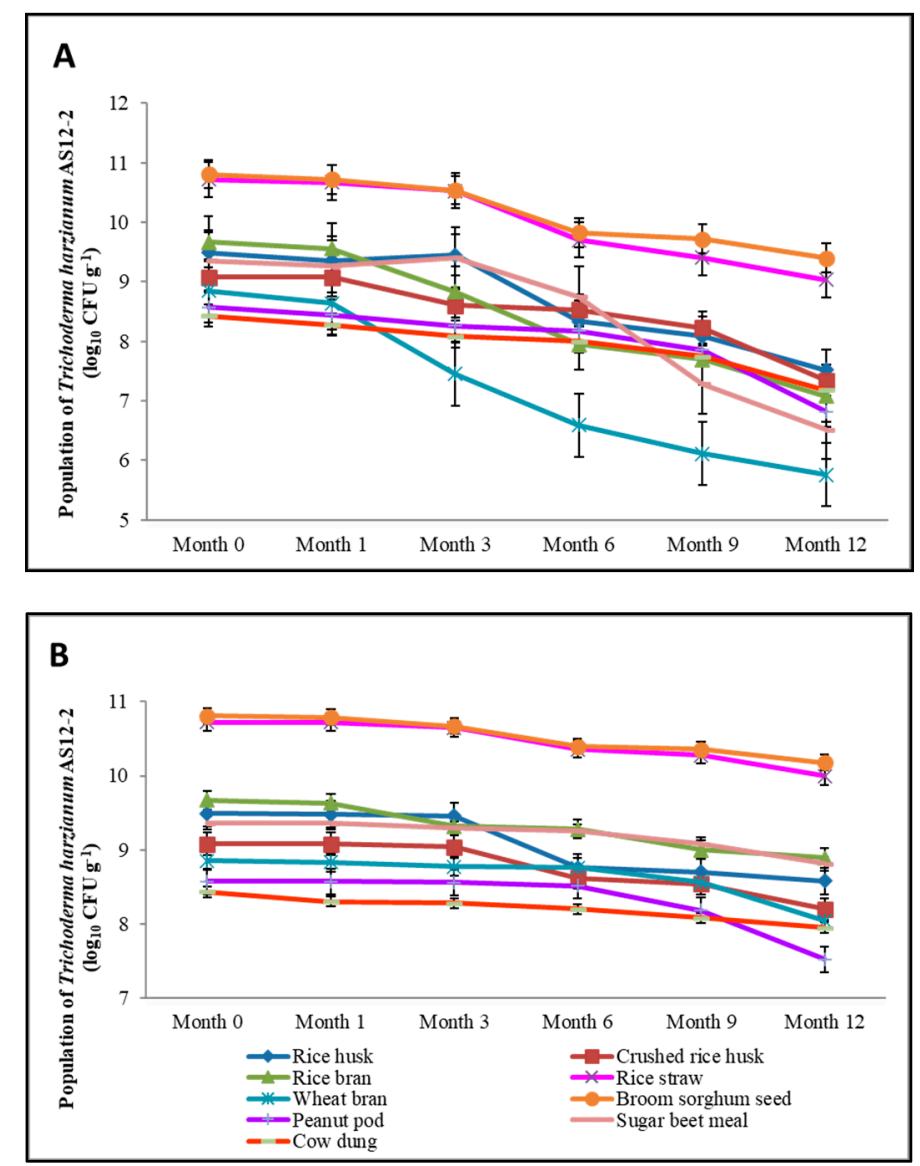

Figure 2. Viability of Trichoderma harzianum AS12-2 in nine organic substrates under solid-state fermentation after different incubation periods (1-12 months) at (A) room temperature $\left(25 \pm 2{ }^{\circ} \mathrm{C}\right)$ and (B) in the refrigerator $\left(4^{\circ} \mathrm{C}\right)$. Bars represent the standard error of the mean.

\subsection{Bioefficacy}

The results of greenhouse assay showed that all selected bioformulations, i.e., broom sorghum grain, rice husk, rice straw, sugar beet pulp and cow dung, were effective in controlling the rice sheath blight disease as compared to the control, and there was no significant difference among these five substrates $(p \leq$ 0.01). The disease severity ranged from $30.24 \%$ to $34.94 \%$ for the bioformulations, while it was $16.90 \%$ and $68.10 \%$ for the propiconazole treatment and infected control, respectively (Table 2, Figure 3). 


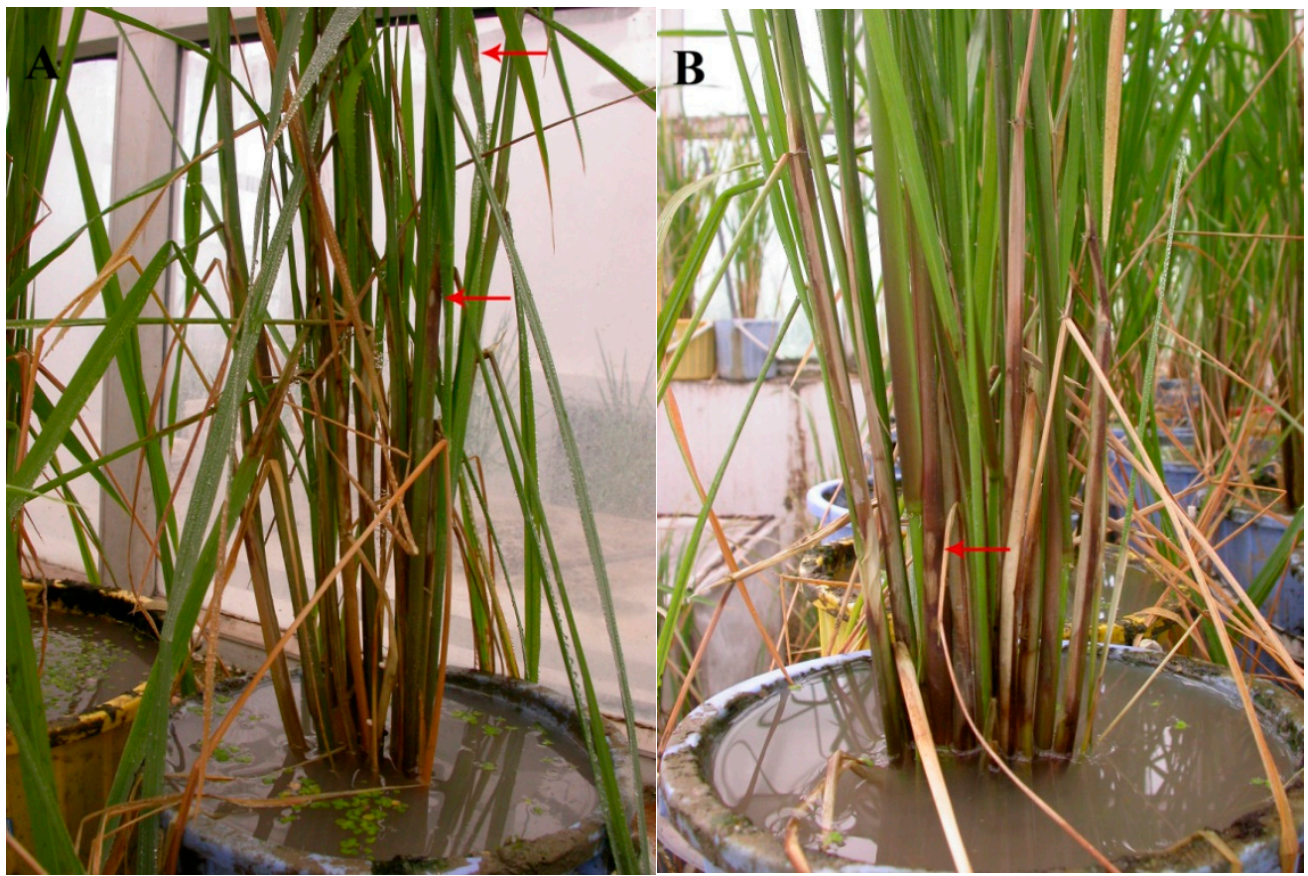

Figure 3. Lesions on rice leaves (shown by red arrows) caused by Rhizoctonia solani. (A) Infected control rice plant inoculated only with $R$. solani. Perceptible lesions are present also at higher parts of the plant, meaning a higher relative lesion length (RLH) and also implying a higher level of severity of the disease. (B) Rice plant inoculated with R. solani and T. harzianum AS12-2. Lesions occur at lower parts of the plant, which means a decreased RLH.

\section{Discussion}

Microbial biopesticides—and Trichoderma-based bioproducts in particular-play an important role in sustainable agricultural production. They are increasing in popularity and sales around the world owing to the changing political and social attitudes, the rise of global concern about the use of agrochemicals, the amount of investment by the large agricultural chemical companies improving products, and the growing demand for organic foods by consumers $[3,8,55,75]$. The establishment of innovative technology for optimizing both quantity and quality is a key factor for the manufacturing of microbial biopesticides. The success of microbial biopesticides in the crop protection market depends not only on the effective antagonists, but also on the costs involved and the method of application $[5,6,8,24,39,62]$. In other words, the mass production systems should be cost-effective and compatible with industrial and commercial development methods and field applications [10]. Intensive studies are needed to select proper fermentation substrates that provide massive, stable and effective microbial populations for the formulation process [76]. Nonetheless, in order to select a suitable substrate for the fermentation process, its availability and cost, as well as the amount and quality of produced conidia, should be considered. We investigated the growth and multiplication of T. harzianum strain AS12-2, on a whole range of different organic materials locally available in northern Iran, in SSF to select suitable agricultural wastes or agriculture by-products that can favor the production of a high amount of microbial biomass with prolonged viability. The successful commercial application of this promising biocontrol agent depends on the production of large quantities of conidia with minimum manufacturing cost. With this in mind, easily available and inexpensive biodegradable substrates were used in the present study to screen for their efficacy in producing mass inoculum of the fungal antagonist and to test its shelf life.

Members belonging to the genus Trichoderma are saprophytic fungi, which grow profusely on a wide range of organic substrates in nature [45]. Most commercial products contain Trichoderma conidia; thus, the high productivity in the SSF system is a critical factor of a successful biocontrol 
agent [77]. Thangavelu et al. [78] evaluated five different organic substrates, i.e., rice bran, rice chaffy grain, farmyard manure, banana pseudostem and dried banana leaf, for SSF of a biocontrol isolate of $T$. harzianum, and reported that dried banana leaf was the best material to support the fungus growth and produced a high density of propagules. Rini and Sulochana [18] studied cow dung, neem cake, coir pith, sorghum grains, sawdust and rice bran as organic substrates for mass production of Trichoderma spp., and they observed the highest initial population in sorghum grains. Singh et al. [79] studied the effect of different agricultural wastes on the conidiation and shelf life of a T. harzianum strain, and indicated that all the substrates resulted in suitable propagation of T. harzianum; however, used tea leaves and wheat bran-sawdust were superior in population count and shelf life, respectively. Cavalcante et al. [42] used low-cost substrates including rice, corn, and wheat brans to produce spores of four different Trichoderma species, and found that wheat bran was the most suitable substrate for the conidium production of all examined Trichoderma strains. Sargin et al. [37] tested various inexpensive agricultural co-products, including wheat bran, sawdust, rice straw, hazelnut shell, grape marc and cotton seed cake, for propagule production of a T. harzianum strain, and reported that the maximum micropropagule count was achieved with a wheat bran-malt sprout mixture. Rayhane et al. [20] studied a fermentation process for enzymes and conidia with a T. asperellum strain and scaled-up the process from flask and glass column to a bioreactor. Fungal growth and sporulation were investigated using a mixture of vine shoots, jatropha cake, olive pomace and olive oil as substrate. The optimum

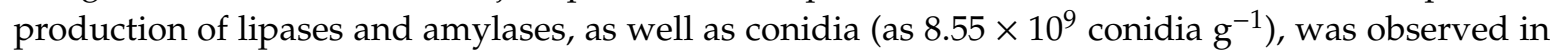
the bioreactor.

Results of the current research showed that T. harzianum AS12-2 grew on all 13 examined solid substrates and abundantly sporulated on them, but the level of colonization and production of biomass differed among the different growth media. This difference reflects the various ingredients in organic substrates and the food preference of the Trichoderma strain. The physicochemical features of organic substrates greatly affect the fermentation process [80]. The best colonization was obtained on rice husk, rice straw, broom sorghum grain, sugar beet pulp, cow dung and water fern, all of them available at very low cost. Surprisingly, rice and wheat brans, which are widely used as organic substrates for the mass production of different fungi including Trichoderma spp. [81-84], resulted in only moderate growth of the biocontrol strain examined in this study. One of the most important criteria for selecting a substrate for SSF is the amount of sporulation of the target microorganism. The fungal population, which is represented as CFU per gram, of a given microbial biopesticide usually affects its bioefficacy in natural systems, and is also a critical factor in quality control experiments when the biopesticides legally face registration processes. Maximum populations of T. harzianum AS12-2 were recorded for broom sorghum grain, rice straw, rice bran, rice husk and sugar beet pulp after one month of incubation of the substrates at room temperature. Among them, higher numbers of conidia were observed on the first two substrates, which were above $1 \times 10^{9} \mathrm{CFU} \mathrm{g}{ }^{-1}$. Flodman and Noureddini [23] reported $7.5 \times 10^{8}$ conidia $^{-1}$ of $T$. reesei using corn cob wastes as a substrate in an Erlenmeyer bioreactor. De la Cruz-Quiroz et al. [44] also used corn cob as a substrate and a plastic bag as a bioreactor for the solid-state fermentation of a T. asperellum strain, and the sporulation rate was $1.4 \times 10^{9}$ conidia $\mathrm{g}^{-1}$. Kaushal and Chandel [85] reported that the highest population count of Trichoderma strains was observed in wheat straw. Rice-based substrates are the most common media for the growth and sporulation of many fungi [25]. Rice straw is rich in cellulose, hemicellulose and lignin, and represents a good source of nutrients for the prolific growth and sporulation of Trichoderma strains [86]. Since the biocontrol strain in this study originated from the rice field, it predictably preferred the rice-based substrate for colonization as well as conidiation. Sala et al. [25] used rice husk in the SSF of T. harzianum and achieved final spore concentrations up to $2.0 \times 10^{9}$ conidia $\mathrm{g}^{-1}$ dry matter. In addition, Sahayaraj and Namasivayam [87] reported that among different substrates, sorghum grain achieved the highest spore production in Paecilomyces fumosoroseus and Verticillium lecanii strains.

According to our results, the extent of colonization does not necessarily correlate with the conidiation of T. harzianum AS12-2 in each substrate. For example, the fungus highly colonized water 
fern, but the CFU number was relatively low on this substrate. On the contrary, in the case of rice bran, despite the moderate colonization, the conidiation was very high. Mascarin et al. [88] also concluded that some substrates favor vegetative growth with low conidium production.

Apart from the CFU, the viability of the biocontrol agent and shelf life of the fungal biomass also play significant roles in successful marketing [10]. In general, the antagonists that multiply in an organic food base have a longer shelf life than in inert or inorganic food bases. In this study, the shelf life of nine air-dried substrates containing biomass of T. harzianum AS12-2 was examined over a period of 12 months at two temperatures. In fact, we monitored the changes of fungal population in each substrate and compared the organic substrates in terms of this trait. The population of the fungus reduced with time after storage of the substrates at room temperature, but the pattern of the decline and the steepness of the curve were different among them. In spite of the considerable viability loss, broom sorghum grain and rice straw showed a very high population at the end and were selected as the best substrates with the longest shelf life after one year of storage at room temperature. Furthermore, despite high initial population, some substrates, i.e., wheat bran and sugar beet meal, showed a considerable decrease in CFUs at Month 12 . In comparison, the viability of T. harzianum AS12-2 in all nine substrates reduced during incubation in the refrigerator, but the population decline was modest compared to that at room temperature, and the final population was relatively high. As expected, fungal viability was highest in broom sorghum grain and rice straw compared to the other substrates. Overall, despite the similarity of patterns, the viability and population of the antagonist in all substrates tended to be less affected by storage at $4{ }^{\circ} \mathrm{C}$ than at room temperature. Reduction in the shelf life of fungal biocontrol agents during storage is consistent with the findings of other researchers, who reported the negative effects of high temperatures and long-term storage on the viability of the inocula of Trichoderma spp. [70,79,89] and other fungi [35,90].

The result of the bioefficacy studies showed that the biocontrol agent produced in five selected substrates significantly and effectively reduced the sheath blight severity as compared to the controls, and there was no statistically significant difference among the substrates regarding the level of disease control.

\section{Conclusions}

The effect of several easily available agricultural by-products was evaluated for solid-state fermentation of a biocontrol agent, and its shelf life was assessed for one year at two temperatures. The current study shows that most of the screened organic substrates can be used to ensure the quantity and quality of T. harzianum AS12-2 inoculum at a low cost. However, the production of a large number of highly viable spores is influenced by the type of the substrate. Although some substrates retain the viability of T. harzianum AS12-2 for a long period, there was a general decline in the number of CFUs in all substrates with the time of storage at both temperatures, with a rapid decrease occurring at room temperature. In other words, T. harzianum AS12-2 survived better at 4 ${ }^{\circ} \mathrm{C}$ (final populations between $3.3 \times 10^{7}$ and $1.0 \times 10^{10} \mathrm{CFU} \mathrm{g}{ }^{-1}$ substrate) than at $25 \pm 2{ }^{\circ} \mathrm{C}$ (final populations between $5.8 \times 10^{5}$ and $2.5 \times 10^{9} \mathrm{CFU} \mathrm{g}^{-1}$ substrate) over a period of 12 months. The maximum CFUs and shelf life were obtained on broom sorghum grain, rice straw, rice husk, sugar beet pulp and cow dung, suggesting a feasible procedure of using agro-industrial wastes for the biomass production of this biocontrol agent. These substrates did not affect the biocontrol potential of T. harzianum AS12-2, suggesting that any of the five substrates could be selected for industrial scale SSF. Scale-up of production is an important factor in developing a laboratory-scale process. Our results suggest that the aforementioned substrates can be recommended as suitable fermentation media for the mass multiplication of Trichoderma strains, and that the SSF process reported here could be scaled up and developed for cost-effective commercial production of Trichoderma-based bio-products. Altogether, industrial-scale production could be achieved with low-cost material and equipment from low total capital investments. 
Author Contributions: Conceptualization, S.N., V.K. and L.K.; Data curation, S.N. and A.V.; Formal analysis, V.K. and C.V.; Funding acquisition, S.N. and C.V.; Investigation, S.N. and V.K.; Methodology, S.N. and L.K.; Project administration, S.N. and L.K.; Resources, V.K. and C.V.; Supervision, L.K.; Validation, V.K. and A.V.; Visualization, A.V.; Writing—original draft, S.N.; Writing—review and editing, V.K., A.V., C.V. and L.K. All authors have read and agreed to the published version of the manuscript.

Funding: This study was supported by Agricultural Research, Education and Extension Organization, Ministry of Agriculture, Iran as a research project (Registration number 52155) and by the Hungarian Government and the European Union within the frames of the Széchenyi 2020 Programme (GINOP-2.3.2-15-2016-00052).

Conflicts of Interest: The authors declare no conflict of interests.

\section{References}

1. Glaeser, B. The Green Revolution Revisited: Critique and Alternative; Routledge Taylor \& Francis Group: London, UK, 2010. [CrossRef]

2. Heckel, D.G. Insecticide resistance after silent spring. Science 2012, 337, 1612-1614. [CrossRef] [PubMed]

3. Glare, T.R.; Caradus, J.; Gelernter, W.; Jackson, T.; Keyhani, N.; Köhl, J.; Marrone, P.; Morin, L.; Stewart, A. Have biopesticides come of age? Trends Biotechnol. 2012, 30, 250-258. [CrossRef] [PubMed]

4. Chandler, D.; Bailey, A.S.; Tatchell, G.M.; Davidson, G.; Greaves, J.; Grant, W.P. The development, regulation and use of biopesticides for integrated pest management. Philos. Trans. R. Soc. B Biol. Sci. 2011, 366, 1987-1998. [CrossRef] [PubMed]

5. Hyakumachi, M. Research on biological control of plant diseases: Present state and perspectives. J. Gen. Plant Pathol. 2013, 79, 435-440. [CrossRef]

6. Moran-Diez, M.E.; Glare, T.R. What are Microbial-based Biopesticides? In Microbial-Based Biopesticides-Methods and Protocols; Glare, T.R., Moran-Diez, M.E., Eds.; Humana Press: New York, NY, USA, 2016; pp. 1-10. [CrossRef]

7. Mwamburi, L.A. Isolation and Assessment of Stability of Six Formulations of Entomopathogenic Beauveria bassiana. In Microbial-Based Biopesticides-Methods and Protocols; Glare, T.R., Moran-Diez, M.E., Eds.; Humana Press: New York, NY, USA, 2016; pp. 85-91. [CrossRef]

8. Abbey, L.; Abbey, J.; Leke-Aladekoba, A.; Iheshiulo, E.M.; Ijenyo, M. Biopesticides and Biofertilizers: Types, Production, Benefits, and Utilization. In Byproducts from Agriculture and Fisheries: Adding Value for Food, Feed, Pharma, and Fuels; Simpson, B.K., Aryee, A.N.A., Toldrá, F., Eds.; John Wiley \& Sons Ltd.: New York, NY, USA, 2020; pp. 479-500. [CrossRef]

9. Azadi, N.; Shirzad, A.; Mohammadi, H. A study of some biocontrol mechanisms of Beauveria bassiana against Rhizoctonia disease on tomato. Acta Biol. Szeged. 2016, 60, 119-127.

10. Cumagun, C.J.R. Advances in Formulation of Trichoderma for Biocontrol. In Biotechnology and Biology of Trichoderma; Gupta, V.K., Schmoll, M., Herrera-Estrella, A., Upadhyay, R.S., Druzhinina, I., Tuohy, M., Eds.; Elsevier: Oxford, UK, 2014; pp. 527-531. [CrossRef]

11. Whipps, J.M. Developments in the biological control for soilborne plant pathogens. Adv. Bot. Res. 1997, 26, 1-134. [CrossRef]

12. Adekunle, A.T.; Cardwell, K.F.; Florini, D.A.; Ikotun, T. Seed treatment with Trichoderma species for control of damping-off of cowpea caused by Macrophomina phaseolina. Biocontrol. Sci. Technol. 2001, 11, 449-457. [CrossRef]

13. Agosin, E.; Aguilera, J.M. Industrial production of active propagules of Trichoderma for agricultural use. In Trichoderma and Gliocladium. Enzymes Biological Control and Commercial Applications; Harman, G.E., Kubicek, C.P., Eds.; Taylor \& Francis Ltd.: London, UK, 1998; Volume 2, pp. 205-227.

14. De La Cruz-Quiroz, R.; Roussos, S.; Hernandez, D.; Rodríguez, R.; Castillo, F.; Aguilar-González, C.N. Challenges and opportunities of the bio-pesticides production by solid-state fermentation: Filamentous fungi as a model. Crit. Rev. Biotechnol. 2014, 35, 1-8. [CrossRef]

15. Lewis, J.A.; Papavizas, G. Biocontrol of plant diseases: The approach for tomorrow. Crop. Prot. 1991, 10, 95-105. [CrossRef]

16. Adivitiya, B.; Pal Khasa, Y. Microbes as Biocontrol Agents. In Probiotics and Plant Health; Kumar, V., Kumar, M., Sharma, S., Prasad, R., Eds.; Springer Nature Pte Ltd.: Singapore, 2017; pp. 507-552. [CrossRef] 
17. Jin, X.; Hayes, C.; Harman, G.E. Principles in the development of biological control systems employing Trichoderma species against plant pathogenic fungi. In Frontiers in Industrial Mycology; Leatham, G.F., Ed.; Chapman \& Hall: New York, NY, USA, 1992; pp. 174-195. [CrossRef]

18. Rini, C.R.; Sulochana, K.K. Substrate evaluation for multiplication of Trichoderma spp. J. Trop. Agric. 2007, 45, $58-60$.

19. Bowers, R.C. Commercialization of microbial biological control agents. In Biological Control of Weeds with Plant Pathogens; Charidattan, R., Walker, H.L., Eds.; John Wiley \& Sons: New York, NY, USA, 1992; pp. 157-173.

20. Rayhane, H.; Josiane, M.; Gregoria, M.; Yiannis, K.; Nathalie, D.; Ahmed, M.; Sevastianos, R. From flasks to single used bioreactor: Scale-up of solid state fermentation process for metabolites and conidia production by Trichoderma asperellum. J. Environ. Manag. 2019, 252, 109496. [CrossRef] [PubMed]

21. Manpreet, S.; Sawraj, S.; Sachin, D.; Pankaj, S.; Banerjee, U.C. Influence of process parameters on the production of metabolites in solid-state fermentation. Malays. J. Microbiol. 2005, 1, 1-9. [CrossRef]

22. Steudler, S.; Werner, A.; Walther, T. It Is the Mix that Matters: Substrate-Specific Enzyme Production from Filamentous Fungi and Bacteria Through Solid-State Fermentation. In Solid State Fermentation, Research and Industrial Applications; Werner, A., Steudler, S., Cheng, J.J., Eds.; Springer Nature: Cham, Switzerland, 2019; pp. 51-81. [CrossRef]

23. Flodman, H.R.; Noureddini, H. Effects of intermittent mechanical mixing on solid-state fermentation of wet corn distillers grain with Trichoderma reesei. Biochem. Eng. J. 2013, 81, 24-28. [CrossRef]

24. Sadh, P.K.; Duhan, S.; Duhan, J.S. Agro-industrial wastes and their utilization using solid state fermentation: A review. Bioresour. Bioprocess. 2018, 5, 1. [CrossRef]

25. Sala, A.; Artola, A.; Sánchez, A.; Barrena, R. Rice husk as a source for fungal biopesticide production by solid-state fermentation using B. bassiana and T. harzianum. Bioresour. Technol. 2019, 296, 122322. [CrossRef] [PubMed]

26. Raimbault, M. General and microbiological aspects of solid substrate fermentation. Electron. J. Biotechnol. 1998, 1, 174-188. [CrossRef]

27. Pandey, A. Aspects of fermenter design for solid-state fermentations. Process. Biochem. 1991, 26, 355-361. [CrossRef]

28. Pandey, A.; Soccol, C.R.; Mitchell, D.A. New developments in solid state fermentation: I-bioprocesses and products. Process. Biochem. 2000, 35, 1153-1169. [CrossRef]

29. Lenz, J.; Hölker, U.; Hofer, M. Biotechnological advantages of laboratory-scale solid-state fermentation with fungi. Appl. Microbiol. Biotechnol. 2004, 64, 175-186. [CrossRef]

30. Bailey, K.; Boyetchko, S.; Längle, T. Social and economic drivers shaping the future of biological control: A Canadian perspective on the factors affecting the development and use of microbial biopesticides. Biol. Control 2010, 52, 221-229. [CrossRef]

31. Thomas, L.; Larroche, C.; Pandey, A. Current developments in solid-state fermentation. Biochem. Eng. J. 2013, 81, 146-161. [CrossRef]

32. Kim, J.H.; Hosobuchi, M.; Kishimoto, M.; Seki, T.; Yoshida, T.; Taguchi, H.; Ryu, D.D.Y. Cellulase production by a solid state culture system. Biotechnol. Bioeng. 1985, 27, 1445-1450. [CrossRef] [PubMed]

33. Shah, P.; Pell, J.K. Entomopathogenic fungi as biological control agents. Appl. Microbiol. Biotechnol. 2012, 61, 413-423. [CrossRef]

34. Bartlett, M.C.; Jaronski, S.T. Mass production of entomogenous fungi for biological control of insects. In Fungi in Biological Control Systems; Gurge, M.N., Ed.; Manchester University Press: Manchester, UK, 1988; pp. 61-85.

35. Larena, I.; Melgarejo, P.; De Cal, A. Production, survival, and evaluation of solid-substrate inocula of Penicillium oxalicum, a biocontrol agent against Fusarium wilt of tomato. Phytopathology 2002, 92, 863-869. [CrossRef] [PubMed]

36. Faria, M.; Wraight, S.P. Mycoinsecticides and Mycoacaricides: A comprehensive list with worldwide coverage and international classification of formulation types. Biol. Control 2007, 43, 237-256. [CrossRef]

37. Sargin, S.; Gezgin, Y.; Eltem, R.; Vardar, F. Micropropagule production from Trichoderma harzianum EGE-K38 using solid-state fermentation and a comparative study for drying methods. Turkish J. Biol. 2013, 37, $139-146$. [CrossRef] 
38. Lewis, J.A. Formulation and delivery systems of biocontrol agents with emphasis on fungi. In The Rhizosphere and Plant Growth. Beltsville Symposia in Agricultural Research; Keister, D.L., Cregan, P.B., Eds.; Springer: Dordrecht, The Netherlands, 1991; pp. 279-287. [CrossRef]

39. Carrizales, V.; Jaffe, W. Solid state fermentation: An appropriate biotechnology for developing countries. Interciencia 1986, 11, 9-15.

40. Carboué, Q.; Claeys-Bruno, M.; Bombarda, I.; Sergent, M.; Jolain, J.; Roussos, S. Experimental design and solid state fermentation: A holistic approach to improve cultural medium for the production of fungal secondary metabolites. Chemom. Intell. Lab. Syst. 2018, 176, 101-107. [CrossRef]

41. Rhodes, D.J. Economics of baculovirus? Insect cell production systems. Cytotechnology 1996, 20, $291-297$. [CrossRef]

42. Cavalcante, R.S.; Lima, H.L.S.; Pinto, G.A.S.; Gava, C.; Rodrigues, S. Effect of moisture on Trichoderma conidia production on corn and wheat bran by solid state fermentation. Food Bioprocess Technol. 2007, 1, 100-104. [CrossRef]

43. Burges, H.D. Formulation of Microbial Biopesticides; Kluwer Academic Publisher: Dordrecht, The Netherlands, 1998.

44. De La Cruz-Quiroz, R.; Roussos, S.; Hernandez-Castillo, D.; Rodriguez-Herrera, R.; López-López, L.I.; Castillo, F.; Aguilar-González, C.N. Solid-State Fermentation in a Bag Bioreactor: Effect of Corn Cob Mixed with Phytopathogen Biomass on Spore and Cellulase Production by Trichoderma asperellum. In Fermentation Processes; IntechOpen: London, UK, 2017; pp. 43-56.

45. Kredics, L.; Hatvani, L.; Naeimi, S.; Körmöczi, P.; Manczinger, L.; Vágvölgyi, C.; Druzhinina, I. Biodiversity of the Genus Hypocrea/Trichoderma in Different Habitats. In Biotechnology and Biology of Trichoderma; Gupta, V.K., Schmoll, M., Herrera-Estrella, A., Upadhyay, R.S., Druzhinina, I., Tuohy, M., Eds.; Elsevier Science B.V.: Amsterdam, The Netherlands, 2014; pp. 3-24.

46. Harman, G.E.; Howell, C.R.; Viterbo, A.; Chet, I.; Lorito, M. Trichoderma species-Opportunistic, avirulent plant symbionts. Nat. Rev. Genet. 2004, 2, 43-56. [CrossRef] [PubMed]

47. Savazzini, F.; Longa, C.M.O.; Pertot, I. Impact of the biocontrol agent Trichoderma atroviride SC1 on soil microbial communities of a vineyard in northern Italy. Soil Biol. Biochem. 2009, 41, 1457-1465. [CrossRef]

48. Howell, C.R. Mechanisms employed by Trichoderma species in the biological control of plant diseases: The history and evolution of current concepts. Plant Dis. 2003, 87, 4-10. [CrossRef]

49. Segarra, G.; Casanova, E.; Bellido, D.; Odena, M.A.; Oliveira, E.; Trillas, I. Proteome, salicylic acid, and jasmonic acid changes in cucumber plants inoculated with Trichoderma asperellum strain T34. Proteome 2007, 7, 3943-3952. [CrossRef] [PubMed]

50. Shoresh, M.; Harman, G.E.; Mastouri, F. Induced systemic resistance and plant responses to fungal biocontrol agents. Annu. Rev. Phytopathol. 2010, 48, 21-43. [CrossRef] [PubMed]

51. Bae, H.; Sicher, R.C.; Kim, M.S.; Kim, S.-H.; Strem, M.D.; Melnick, R.L.; Bailey, B.A. The beneficial endophyte Trichoderma hamatum isolate DIS $219 \mathrm{~b}$ promotes growth and delays the onset of the drought response in Theobroma cacao. J. Exp. Bot. 2009, 60, 3279-3295. [CrossRef]

52. Lorito, M.; Woo, S.L.; Harman, G.E.; Monte, E. Translational research on Trichoderma: From 'Omics to the field. Annu. Rev. Phytopathol. 2010, 48, 395-417. [CrossRef]

53. Harman, G.E. Trichoderma-Not just for biocontrol anymore. Phytoparasitica 2011, 39, 103-108. [CrossRef]

54. Hanhong, B. Trichoderma species as abiotic and biotic stress quenchers in plants. Res. J. Biotechnol. 2011, 6, 73-79.

55. Woo, S.L.; Ruocco, M.; Vinale, F.; Nigro, M.; Marra, R.; Lombardi, N.; Pascale, A.; Lanzuise, S.; Manganiello, G.; Lorito, M. Trichoderma-based products and their widespread use in agriculture. Open Mycol. J. 2014, 8, 71-126. [CrossRef]

56. Verma, M.; Brar, S.K.; Tyagi, R.D.; Surampalli, R.; Valero, J. Antagonistic fungi, Trichoderma spp.: Panoply of biological control. Biochem. Eng. J. 2007, 37, 1-20. [CrossRef]

57. Mendoza-Mendoza, A.; Clouston, A.; Li, J.-H.; Nieto-Jacobo, M.F.; Cummings, N.; Steyaert, J.; Hill, R. Isolation and Mass Production of Trichoderma. In Microbial-Based Biopesticides, Methods in Molecular Biology; Glare, T.R., Moran-Diez, M.E., Eds.; Humana Press: New York, NY, USA, 2016; Volume 1477, pp. 13-20. [CrossRef]

58. Papavizas, G.C.; Lewis, J.A. Introduction and Augmentation of Microbial Antagonists for the Control of Soilborne Plant Pathogens. In Biological Control in Crop Production; Papavizas, G.C., Ed.; Allanheld, Osmun Publishers: Totowa, NJ, USA, 1981; pp. 305-322. 
59. Papavizas, G.C. Trichoderma and Gliocladium: Biology, Ecology, and Potential for Biocontrol. Annu. Rev. Phytopathol. 1985, 23, 23-54. [CrossRef]

60. Harman, G.; Jin, X.; Stasz, T.; Peruzzotti, G.; Leopold, A.; Taylor, A. Production of conidial biomass of Trichoderma harzianum for biological control. Biol. Control 1991, 1, 23-28. [CrossRef]

61. Jin, X.; Harman, G.; Taylor, A. Conidial biomass and desiccation tolerance of Trichoderma harzianum produced at different medium water potentials. Biol. Control 1991, 1, 237-243. [CrossRef]

62. Keswani, C.; Bisen, K.; Singh, V.; Sarma, B.K.; Singh, H.B. Formulation Technology of Biocontrol Agents: Present Status and Future Prospects. In Bioformulations: For Sustainable Agriculture; Springer: New Delhi, India, 2016; pp. 35-52. ISBN 978-81-322-2779-3.

63. Ridder, E.R.; Nokes, S.E.; Knutson, B.L. Optimization of solid-state fermentation parameters for the production of xylanase by Trichoderma longibrachiatum on wheat bran. Trans. ASAE 1998, 41, 1453-1459. [CrossRef]

64. Kakvan, N.; Heydari, A.; Zamanizadeh, H.R.; Rezaee, S.; Naraghi, L. Development of new bioformulations using Trichoderma and Talaromyces fungal antagonists for biological control of sugar beet damping-off disease. Crop. Prot. 2013, 53, 80-84. [CrossRef]

65. Motta, F.L.; Santana, M.H.A. Solid-state fermentation for humic acids production by a Trichoderma reesei strain using an oil palm empty fruit bunch as the substrate. Appl. Biochem. Biotechnol. 2013, 172, 2205-2217. [CrossRef]

66. Zhang, J.; Yang, Q. Optimization of solid-state fermentation conditions for Trichoderma harzianum using an orthogonal test. Genet. Mol. Res. 2015, 14, 1771-1781. [CrossRef]

67. De La Cruz-Quiroz, R.; Robledo-Padilla, F.; Aguilar-González, C.N.; Roussos, S. Forced aeration influence on the production of spores by Trichoderma strains. Waste Biomass_Valorization 2017, 8, 2263-2270. [CrossRef]

68. Al-Taweil, H.I.; Bin Osman, M.; Hami, A.A.; Yusoff, W.M.W.; Aidil, A.H.; Yussof, W.M. Optimizing of Trichoderma viride cultivation in submerged state fermentation. Am. J. Appl. Sci. 2009, 6, 1284-1288. [CrossRef]

69. Munoz, G.; Agosin, E.; Cotoras, M.; San Martin, R.; Volpe, D. Comparison of aerial and submerged spore properties of Trichoderma harzianum. Curr. Genet. 1995, 32, 225-230. [CrossRef]

70. Jackson, A.; Whipps, J.; Lynch, J. Production, delivery systems, and survival in soil of four fungi with disease biocontrol potential. Enzyme Microb. Technol. 1991, 13, 636-642. [CrossRef]

71. Naeimi, S.; Okhovvat, S.M.; Javan-Nikkhah, M.; Vágvölgyi, C.; Khosravi, V.; Kredics, L. Biological control of Rhizoctonia solani AG1-1A, the causal agent of rice sheath blight with Trichoderma strains. Phytopathol. Med. 2010, 49, 287-300. [CrossRef]

72. Naeimi, S.; Khosravi, V.; Nouri, M.-Z.; Hoda, H.; Vágvölgyi, C.; Kredics, L. Biological control of rice sheath blight disease with formulation of indigenous Trichoderma strains under paddy field conditions. Acta Biol. Szeged. 2019, 63, 37-43. [CrossRef]

73. Naeimi, S.; Khodaparast, S.A.; Javan-Nikkhah, M.; Vágvölgyi, C.; Kredics, L. Phylogenetic relationship of Trichoderma species isolated from paddy fields of Mazandaran province based on sequence analysis of tef $1 \alpha$ gene. Iran. J. Plant Pathol. 2014, 50, 139-149.

74. IRRI. IRRI: Standard Evaluation System for Rice, 4th ed.; International Rice Research Institute: Manila, Philippines, 1996.

75. Olson, S. An Analysis of the Biopesticide Market Now and Where it is Going. Outlooks Pest Manag. 2015, 26, 203-206. [CrossRef]

76. Hynes, R.K.; Boyetchko, S.M. Research initiatives in the art and science of biopesticide formulations. Soil Boil. Biochem. 2006, 38, 845-849. [CrossRef]

77. Steyaert, J.M.; Weld, R.J.; Mendoza-Mendoza, A.; Stewart, A. Reproduction without sex: Conidiation in the filamentous fungus Trichoderma. Microbiol. 2010, 156, 2887-2900. [CrossRef]

78. Thangavelu, R.; Palaniswami, A.; Velazhahan, R. Mass production of Trichoderma harzianum for managing fusarium wilt of banana. Agric. Ecosyst. Environ. 2004, 103, 259-263. [CrossRef]

79. Singh, A.; Srivastava, S.; Singh, H.B. Effect of substrates on growth and shelf life of Trichoderma harzianum and its use in biocontrol of diseases. Bioresour. Technol. 2007, 98, 470-473. [CrossRef]

80. Li, G.; Fu, Y.; Dang, W.; Hu, R.; Xue, H. The effects of aqueous ammonia-pretreated rice straw as solid substrate on laccase production by solid-state fermentation. Bioprocess Biosyst. Eng. 2019, 42, 567-574. [CrossRef] [PubMed] 
81. Lumsden, R.; Lewis, J. Selection production, formulation and commercial use of plant disease biocontrol fungi. Problems and Progress. In Biotechnology of Fungi for Improving Plant Growth; Whipps, J., Lumsden, R., Eds.; Cambridge University Press: Cambridge, UK, 1988; pp. 171-189.

82. Rama, S.; Singh, H.; Singh, P.; Kaur, J. A comparison of different substrates for the mass production of Trichoderma. Ann. Plant Prot. Sci. 2001, 9, 248-253.

83. Tewari, L.; Bhanu, C. Evaluation of agro-industrial wastes for conidia based incoulum production of biocontrol agent: Trichoderma harzianum. J. Sci. Ind. Res. 2004, 6, 807-812.

84. Gupta, M.; Mahajan, S.; Sharma, D.; Gupta, S.; Mallick, S.A. Agrowastes as substrates for hydrolytic enzymes and biomass production of native isolates of Trichoderma spp. Indian Phytopathol. 2016, 69, 558-564.

85. Kaushal, S.; Chandel, S. Enhancing the shelf life of Trichoderma species by adding antioxidants producing crops to various substrates. J. Crop. Prot. 2017, 6, 307-314.

86. El-Tayeb, T.; Abdelhafez, A.; Ali, S.; Ramadan, E. Effect of acid hydrolysis and fungal biotreatment on agro-industrial wastes for obtainment of free sugars for bioethanol production. Braz. J. Microbiol. 2012, 43, 1523-1535. [CrossRef]

87. Sahayaraj, K.; Namasivayam, S.K.R. Mass production of entomopathogenic fungi using agricultural products and by products. Afr. J. Biotechnol. 2008, 7, 1907-1910. [CrossRef]

88. Mascarin, G.M.; Alves, S.B.; Lopes, R.B. Culture media selection for mass production of Isaria fumosorosea and Isaria farinosa. Braz. Arch. Boil. Technol. 2010, 53, 753-761. [CrossRef]

89. Steinmetz, J.; Schönbeck, F. Conifer bark as growth medium and carrier for Trichoderma harzianum and Gliocladium roseum to control Pythium ultimum on pea. Zeitsch. Pflanzenkrankh. Pflanzenschutz 1994, 101, 200-211.

90. McQuilken, M.P.; Whipps, J.M. Production, survival and evaluation of solid-substrate inocula of Coniothyrium minitans against Sclerotinia sclerotiorum. Eur. J. Plant Pathol. 1995, 101, 101-110. [CrossRef]

(C) 2020 by the authors. Licensee MDPI, Basel, Switzerland. This article is an open access article distributed under the terms and conditions of the Creative Commons Attribution (CC BY) license (http://creativecommons.org/licenses/by/4.0/). 